\title{
Africa's "too little debt" crisis: why finance from China to African countries is more crucial than ever in the wake of COVID-19
}

\author{
Hannah Ryder ${ }^{1} \cdot$ Yike Fu $^{1}[$
}

Received: 17 May 2021 / Accepted: 31 August 2021 / Published online: 21 September 2021

(C) The Institute of International and Strategic Studies (IISS), Peking University 2021

\begin{abstract}
As COVID-19 has spread across the world, including the African continent, concerns have been raised about the impending debt crisis in Africa, given the fact that levels of debt—including loans from China-have grown in recent years. This paper argues that these concerns are highly subjective and are often based on colonial attitudes about African competence in dealing with domestic challenges. The paper attempts to provide a clearer, impartial understanding of Africa's history with debt by emphasizing African agency and reviewing three key periods of debt challenges and their implications for today's debt situation. By doing so, the paper suggests that rather than a crisis of too much debt, African governments are currently facing a crisis of access to cheap finance and need considerably more finance to recover from COVID-19 and meet the Sustainable Development Goals adopted by the United Nations in 2015. The paper also analyzes China's role in African debt to date and argues that China has been very helpful, especially in the context of the decline in concessional finance for infrastructure from other development partners since the 2000s. The paper further calls for a reimagining of the international debt system in Africa's favor. The paper concludes by providing clear recommendations for African governments, the international community, and China. The paper suggests that the international community must make adjustments, including systemic changes to how levels of debt and returns are assessed in African countries, for African countries to find innovative, low-risk ways to access finance. Otherwise, a debt crisis of the scale of that of the 1990s may well reemerge. China can help by continuing to provide and even scale up concessional finance for African borrowers, as well as by helping African countries secure favorable changes to the international financing system.
\end{abstract}

Keywords African debt - China's role · China-Africa relations · Development financing $\cdot$ Sustainable Development Goals

Yike Fu

yikefu@developmentreimagined.com

Extended author information available on the last page of the article 


\section{Introduction}

With regard to dealing with and managing the shock of the COVID-19 pandemic, the African continent may well be the most proactive in the world. However, there are potential forces, especially debt, that may lead it to suffer greatly in the years to come.

The last African debt crisis, which began in the 1980s and continued into the early 2000s, began as a result of commodity shocks that led to an increase in the interest rates on loans taken by developing countries, many emerging from colonization, to finance their growth and development in the 1960s and 1970s. The structural adjustment programs that ostensibly aimed to reduce the debt caused by this increase in interest rates left many countries with even more debt.

In recent years, growing levels of debt-including loans from China-have raised concerns about an impending debt crisis in Africa. Specifically, many are worried that increasing government expenditures in the face of the COVID-19 pandemic may trigger a new crisis in the years to come. At the same time, China has been accused of wielding "debt diplomacy" to gain certain advantages and benefits in exchange for loans.

Are these narratives correct? Does the evidence really point in these directions?

This article aims to address these questions by investigating the issue of African debt and China's role in it. It provides recommendations-including recommendations for China-that advance the progress and agency of Africans. In particular, the article argues that the primary challenge that Africa currently faces is not debt itself, but rather finding new and innovative ways to help the continent receive more funds to fill its financing gaps and fulfill its need for accelerated economic growth and jobs to alleviate poverty. It argues that China can play a helpful role in meeting this challenge.

\section{The existing literature: two narratives}

To understand the literature and evidence on Africa's COVID-19 debt crisis and China's role, it is important to understand the existing literature on Africa's last debt crisis. There are two different narratives in the literature with regard to the reasons for the last African debt crisis and the response to it.

The first and common narrative emphasizes the profligacy of African governments post-independence and the efforts of the international community to "rescue" African countries from this challenge. The narrative tends to read as follows:

Starting in the 1960s, the public spending of African countries post-independence surged as governments sought to stimulate their economies through massive investment in industry and infrastructure project construction. A rise in commodity prices and heavy use of external debt supported this spending, but countries increasingly relied on export earnings and borrowed more loans to fill the gap during negative commodity shocks. This trend led to the subsequent debt crisis 
in the 1980s, when interest rates in developed countries rose and capital inflows declined. The Paris Club, World Bank, and International Monetary Fund worked hard to help. They established the Heavily Indebted Poor Countries Initiative in 1996 and the Multilateral Debt Relief Initiative in 2005 to provide debt relief and reduce debt service payments for eligible countries, including countries in Africa (Onyekwena and Ekeruche 2019). Through these measures and recipient governments' commitment to structural reforms and well-structured debt management strategies, debt levels were eventually brought down to acceptable levels in the early 2000s (Khan and Ajayi 2000).

This narrative continues to the present day, arguing that since 2000, African governments have resumed overspending. For instance, in 2015, the World Bank argued that African countries have too much debt and encouraged borrowers to change their behaviors and adjust their risks (Battaile et al. 2015). Further, within this narrative, the role of China in providing loans has been controversial-even more so than, for instance, private sector debt, such as the "Eurobonds" that have also risen rapidly since the 2000s, especially in Africa's middle-income countries. China has been accused of using its lending to vulnerable countries for strategic purposes. For instance, in 2019, Mark Green, the former Administrator of the U.S. Agency for International Development, argued that China uses "debt diplomacy" to convert its economic might into political influence in recipient nations, especially when those recipient nations are unable to repay their debt. Mr. Green also claimed that unlike the Paris Club, China does not provide debt relief to help recipient countries reduce their debt burden, as evidenced by the recent increase in the size of Chinese debt held by heavily indebted poor countries. Unsustainable Chinese debt threatens the self-reliance of those vulnerable countries (Green 2019).

What is left out of this first narrative is just as important as what is mentioned. For instance, the narrative does not focus on the external lending environment as a causal factor for the first debt crisis, nor does it acknowledge the negative impact of the IMF and World Bank's conditional structural adjustment policies. It also does not mention that financing from Paris Club donors and multilaterals has essentially declined as African countries and their need for financing for infrastructure and other challenges, such as climate change, have grown.

This first narrative is devoid of an African understanding and perspective on debt and borrowing more broadly. The second narrative-to which the rest of this paper adheres-is different. This narrative instead focuses on the borrower's perspective, both in terms of using debt to finance real needs, including infrastructure, climate change, and more recently COVID-19, as well as the pros, cons, and distinct challenges of different lenders, including China. For instance, in recent years, a literature has emerged around the challenges that Africa is exposed to with respect to private creditors. First, African countries need to pay higher-than-norm coupon rates on private sovereign bond markets, which burdens it with debt repayment—-the so-called "Africa Risk Premium" (Olabisi and Stein 2015). Second, the sovereign credit rating system is problematic. Sovereign credit ratings do not fully represent economic performance in Africa. An increase in economic growth in Africa does not increase the likelihood of receiving an upgraded sovereign credit rating, which means that macroeconomic factors in Africa are relatively less important than those in developed 
countries in determining country's risk profiles (Mutize and Nkhalamba 2020). African countries' difficulties in receiving upgraded sovereign credit ratings directly lead to situations in which investors are concerned about the market environment in Africa, which in turn leads to decreased investment. There are other examples of literature that also explore the role of multilateral lenders and the Paris Club from the borrower's perspective.

However, within this literature, China's past and current role is unclear. Thus, this article seeks to fill this gap based on the second narrative, which emphasizes African agency, so as to provide insights especially with respect to the future role of China in African debt.

\section{Africa's history with debt}

To understand Africa's current debt, we must begin by viewing and understanding Africa's debt history from an African perspective.

The history of African debt post-colonialization can be traced back to the 1970s, when African countries started using credit from the International Monetary Fund (IMF). Africa's debt situation can be categorized into three distinct periods:

The first period refers to the late 1960s and early 1970s, when the continent experienced the fallout of the first global oil price shock and rising commodity pricesin other words, an externally created shock to the continent. Many African governments, most coming out of colonization and seeking to build national public goods for their citizens, initially benefited from a commodity price boom and spent government expenditure on infrastructure. In addition, the oil price shock created what is known as the OPEC surplus, which forced oil importers to become more dependent on borrowing. The surplus was spread through the international banking system, making loans from the Euromarket relatively cheap and thus an important source of financing for several African countries (Fole 2003). Based on the author's calculations and World Bank data, the average external debt to gross national income ratio for African countries was $21 \%$ in 1970 .

The second period refers to the later 1970s and early 1980s, when the second global oil price shock, coupled with the lax fiscal and tight monetary policy of the US, caused high global interest rates and a significant fall in commodity prices, leading the revenues of many African governments to decrease. Thus, governments needed to borrow from outside lenders to fill the financing gap. African governments continued borrowing to pay for enlarged oil bills and to avoid any reductions in government expenditure. These governments included those of Ghana, Zambia, Malawi, and Nigeria (Fole 2003). By 1980, based on the author's calculations and World Bank data, the average external debt to gross national income ratio for African countries was $49 \%$.

The third period refers to the late 1980s and the 1990s, when the price of commodities further declined and trade deteriorated as a result. Between 1985 and 1990, despite the fact that export volumes increased by $75 \%$, there was a $40 \%$ decline in average export revenue in Africa, constraining African countries' growth. This made them heavily indebted relative to their economies by the end of the 1990s (Fole 
2003). During the 1990s, the average external debt to gross national income ratio was $111 \%$ - significantly greater than the equivalent figures of the two prior periods.

It is important to realize two key points about these three periods. First, African debt only actually rose in volume terms during the earlier two periods. Second, the distress African countries experienced in the 1990s had nothing to do with their own economies; it was caused by the external environment and their overreliance on international trade and markets for their growth. What do these points imply for today's situation?

\subsection{The implications for today's debt situation}

Today, African countries are being accused of having taken too much debt, with the majority classified by the IMF and World Bank as at risk of or already in debt distress, in part as a result of loans from China (as discussed later in this paper).

However, since 2000, the African debt situation has been improving. While debt has been rising in absolute terms, debt as a percentage of gross national income has fallen. In fact, Africa is currently at 1978 levels of debt-levels from well before the debt crisis of the 1990s. In 2019, the external debt to gross national income ratio for the continent was $44 \%$, relatively close to the 1978 ratio of $43 \%$. Moreover, the total external debt owed by Africa's 55 countries was 775 billion, which is roughly equivalent to the amount owed by some individual countries to external creditors (Development Reimagined 2020). For instance, this figure is 1.4 times the amount owed by Brazil and 2 times the amount owed by Indonesia. China owes 2.5 times this amount to external creditors.

It is of course possible that COVID-19 could lead to a major shift in Africa's debt to GDP ratio, even if no further loans are forthcoming from Africa's partners. In 2019, African economies on average grew by 3.5\%, and four of the world's ten fastest growing countries were in Africa: Rwanda (9.4\%), Ethiopia (9.0\%), Djibouti (7.5\%), and Tanzania (7\%). Prior to COVID-19, the IMF forecast that 2020 would see on average higher rates of growth in the African continent: 4\%. After COVID-19 hit, the IMF initially revised its forecast for average growth on the continent to negative $2.3 \%$. In its most recent update, the IMF suggests that Africa's economy will contract by $2.9 \%$ in 2020 , followed by a recovery in 2021 of $3.7 \%$ growth (World Economic Outlook Database 2020). ${ }^{1}$

On the other hand, while the COVID-19 pandemic led to a significant downturn for the global economy in 2020, China has largely recovered and expects to experience new growth in 2021, especially with the development of new vaccines. The 2020 downturn in the global economy is a temporary setback. Ceteris paribus, it is not clear how the current economic downturn could possibly trigger a new debt crisis for Africa in comparison to the rest of the world.

${ }_{1}$ All figures exclude Libya. 


\section{Challenges for African debt}

However, there are two important caveats or internal challenges to bear in mind regarding Africa's debt situation.

First, it is important for African countries to have strategies to deal with current debt payments and avoid any escalation into crisis because of a lack of liquidity. Second, there are some countries in Africa that are more indebted and vulnerable than others. We now turn to these two issues.

\subsection{The first major internal challenge for African debt: spending today}

Challenges to dealing with Africa's debt emanate both from within the continent and outside it. First, COVID-19 has severely affected the global economy, and global lockdown has made it difficult for African countries to gain tax revenue as usual. Therefore, it is questionable whether African countries have the ability to pay off interest and other debt service requirements on time.

It has already proven and will continue to be hugely challenging for African governments to repay loans on time in 2021 due to dramatically reduced financial inflows and mounting internal costs due to COVID-19. As noted earlier, based on data compiled by Development Reimagined, by the end of September 2020, African governments had budgeted over US\$68 billion to respond to COVID-19-an average of 2.6 percent of African countries' combined GDP. This spending has been directed towards medical equipment, tests, and hospitals, as well as toward support for over 175 million African people to compensate for shutdowns of homes and formal and informal businesses and to avoid an estimated 28-49 million more people entering poverty due to COVID-19 (Lufumpa 2020).

2.6 percent of GDP is small compared to the amount spent by the rest of the world to combat COVID-19. For example, Asian and Pacific countries spent 7 percent of their GDP over the same time period, while the 20 most powerful countries in the world - the G20-are estimated to have spent roughly $11.2 \%$ of their GDP on their domestic COVID-19 responses in 2020. However, this spending does create a dent in African governments' finances.

Due to unavoidable COVID-19 spending, African governments do not have enough room to spend on other areas. First, few countries are growing economically, let alone collecting new taxes. As noted earlier, a $2020 \mathrm{IMF}$ analysis predicted an overall fall of $2.9 \%$ of GDP on average across the continent in 2020 (International Monetary Fund 2020b). Further, on average, Sub-Saharan African governments only manage to collect $17 \%$ of their GDP as taxes, compared to $19 \%$ in China and over 30\% in OECD countries (State Tax Administration of the People's Republic of China 2018; Organization for Economic Co-operation and Development 2020).

At the same time, African countries are required to repay loans from multiple lenders: from other governments, such as the US, UK, Japan, France and China; from multilateral banks, such as the IMF, World Bank, and African Development Bank; from commercial private banks, such as Goldman Sachs; and from various state-owned banks, such as China Exim Bank or India Exim Bank. They have used 
these loans for infrastructure; recurrent expenditure, such as key worker and civil servant salaries; and medical equipment and vaccines for life-threatening diseases. These loans have different repayment schedules: some have grace periods, some do not; some have high and variable interest rates, some do not earn any interest; some need to be repaid within 5 years, others within 30 years.

There are only three African countries that have debt levels around or larger than the current size of their economies: Djibouti, Mauritania, and Mozambique. If these countries do not grow at all during the COVID-19 pandemic, they may face significant challenges in the future. In addition, there are eight African countries-Djibouti, Mauritius, Angola, South Africa, Nigeria, Ghana, Cote D'Ivoire, and Botswana-who had to pay over $10 \%$ of the value of their total debt in debt service payments in 2020. It can be concluded that their premiums are very high, which may indicate a sustainability problem. Last, there are seven African countries who owe over a third of their debt to private creditors, for instance via Eurobonds, with Mauritius, Nigeria, and Zambia owing over $40 \%$. This could pose an immediate challenge, as private creditors have been very reluctant in the past to negotiate debt relief.

This is why the G20 initiative to suspend debt service payments to the bilateral lenders for 76 poor countries around the world - freeing up a maximum of $\$ 6$ billion dollars in 2020 and more in 2021-has been so useful and important. The challenge it leaves, however, is that several of the above-mentioned countries with the largest immediate challenges cannot qualify for the initiative because it is restricted to lowincome countries. Yet, many of those countries that have entered middle-income status have done so with the support of loans. The G20 initiative also does not include private sector creditors, multilateral banks, or Chinese commercial banks, which means many countries will nevertheless have to pay a significant amount of service payments in 2020. While some multilateral banks such as the World Bank are providing new grants to help cover service payments to compensate for not taking part in the initiative, they are only doing so for low-income countries. The IMF is providing new loans to middle-income countries to help, but these loans have short repayment schedules. The result of these shortcomings could be an easily foreseen crisis for some African countries over the next few years.

\subsection{The second major internal challenge for African debt: growth vulnerability}

The second major challenge for African debt is growth vulnerability, or put differently, the poor diversification of economies in Africa. Countries that largely depend on hard-hit global industries such as commodities, trade, and tourism have certainly proved more vulnerable to the negative effects brought by COVID-19, and this has shown itself to be the case in Africa. Some African economies-though not the majority-fall into these three vulnerable categories, bringing into question their future debt repayment ability.

Commodity dependent economies were the first to demonstrate their vulnerability to the price volatility caused by the COVID-19 shock, including an early and substantial decline in oil prices. As a result, for example, the IMF forecasts a $5.4 \%$ 
recession in Nigeria in 2020. While Nigeria has a relatively low debt to GNI ratio of about $12 \%$, overdependence on the oil sector becomes a problem for debt when oil revenue generation is low. Nigeria may spend close to all its 2020 government revenue on debt service payments (Nairametrics 2020).

Another vulnerability is high inward trade dependency. Countries like South Africa and Egypt, which together own over a third of Africa's debt and depend on both inward and outward trade, have suffered a double whammy: reduced demand for their goods as well as higher import prices and therefore domestic inflation. As a result, their economies are expected to decline. The IMF forecasts a difficult 7.2\% contraction in South Africa, whose economy was already in recession by the end of 2019-its third since 1994.

The final but perhaps most challenging vulnerability is dependency on tourism. The tourism industry has been decimated by COVID-19 due to border closures and travel restrictions. While Africa as a whole attracts few global tourists-just $4 \%$ of the world's total-there are some tourism dependent African economies like Morocco, Mauritius, Seychelles, Tunisia, and Tanzania that have been left exposed. For Tunisia, a relatively high debt to GNI country (90\%) where the tourism sector accounts for almost $10 \%$ of overall GDP, tourism revenues declined by $50 \%$ in the first 5 months of 2020. Although Tunisia reopened its borders after months of lockdown, it continues to face several new waves of the pandemic, and its economy was expected to shrink by 7\% in 2020 (Amara and Harrison 2020).

These three vulnerabilities create major concerns for these African economies. As COVID-19 continues to ravage the global economy and African countries experience restricted access to vaccines, these vulnerabilities call into question whether these countries can grow sufficiently in and beyond 2021 to be able to pay debt services or take more loans out in future.

However, rather than simply suggesting that a full-blown African debt crisis is happening and that debt relief and cancellation are necessary, this analysis suggests a very different international response to Africa's COVID-19 challenges by Africa's development partners.

\subsection{The major external challenge for African debt: correcting misunderstanding}

The fact is, there is significant misunderstanding about Africa's debt situation from outside of Africa. Although COVID-19 has made it difficult for African governments to meet current debt service payments, it does not expose a looming debt crisis resulting from excessive loans or debt. The narrative that Africa as a whole is entering an unavoidable debt crisis due to COVID-19 has a poor evidence basis. Indeed, within Africa, $84 \%$ of all debt is owed by just 16 countries; the vast majority of African countries have external debt ratios equivalent to less than $50 \%$ of their GDP. This means African debt levels can easily be managed—by lenders including China and others-as an overall portfolio of diversified debt.

So, what is the problem for Africa? The problem is a lack of access to financing. Debt is not a dirty word; rather, it can be very helpful. The majority of individuals across the world have debt, from microloans to mortgages. The majority of 
governments have debt as well. Governments often need to take on debt to pay for roads, trains, and new housing projects or to invest in improving the quality of their education or health systems. There is no harm in taking on debt for useful projects that contribute to economies and raise living standards.

Moreover, before COVID-19, the African Development Bank assessed that African countries cannot raise sufficient taxes or other funds domestically for all their basic infrastructure needs (African Development Bank 2018, 63-94). African governments must look externally. Specifically, the continent needs extra finance to pay for a massive US\$68-\$108 billion worth of infrastructure every year up to 2030, aside from all the other key requirements of their citizens. In the post-COVID-19 era, the need for development infrastructure will arguably be even greater. For example, roads and trains are needed to transport medical equipment and food across borders. COVID-19 requires fiber-optic cables for children to e-learn from home and for rural communities to access digitized government services. New power plants are needed to run factories. And even more finance is needed to make Africa's infrastructure low-carbon and climate resilient and to ensure that countries that are vulnerable to COVID-19-like crises are able to diversify their economies away from dependency on, for instance, commodities, trade, and tourism. As a result, more, not less, debt will be needed in a post-COVID-19 period to develop Africa.

\section{What is helpful to Africa?}

\subsection{China's role in African debt so far}

There is no doubt that China and Africa's 53 countries with diplomatic relations with China, as well as the African Union (AU) itself, currently have strong relations and solid cooperation. In particular, from China's perspective, China has supported Africa's development for a long time, including through phases of essential infrastructure development. Specifically, 2020 marked the 20th anniversary of the establishment of the Forum on China-Africa Cooperation (FOCAC). Chinese government figures show that China-Africa trade amounted to US\$208.7 billion in 2019 and Chinese direct investment stock in Africa accounted for US\$49.1 billion, 20 times and 100 times more than 20 years ago, respectively. China has built more than $6,000 \mathrm{~km}$ of roads and highways and developed nearly 20 ports and more than 80 power facilities in Africa (Ministry of Foreign Affairs of the People's Republic of China 2020a). In recent years, China has also changed its approach to Africa from the traditional model of "resources for infrastructure" to equity investment by a more diverse group of investors. China aims to offer a market-based approach that provides opportunities for African countries to speed up economic development and utilize technologies and market opportunities created by China (Sun 2020). In addition, China has adopted a flexible capital approach comprised of grants, preferential loans, and blended methods to support African countries in capacity building. For instance, during the 2018 Beijing Summit of FOCAC, President Xi announced that China will extend $\$ 60$ billion dollars of financing to Africa in the form of grants, 
loans, and special funds. Chinese companies were also encouraged to invest at least $\$ 10$ billion dollars in Africa by the end of 2021 (Xinhua 2018).

However, what does China as a lender represent to African nations?

As mentioned earlier, China is often accused of utilizing "debt diplomacy" to gain certain policy advantages in exchange for loans. Chinese lending is still seen as fairly opaque. Further, estimates for the proportion of loans provided by China to developing countries vary widely, which provides room to question and criticize the true amount of Chinese loans. For instance, a study by the Jubilee Debt Campaign (2018) suggests that 20 percent of the debt owed by 48 African countries is owed to China, in comparison to the 35 percent owed to multilateral institutions, 32 percent to private creditors, and the remaining 13 percent to the Paris Club-bilateral lenders such as the US, UK, and France. A recent IMF paper suggests that since 2010, private sector bonds have been the fastest growing source of finance for several low-income countries (International Monetary Fund 2020a). In contrast, Horn et al. (2019) claim that for low-income countries between 2010 and 2015, total lending from China exceeded lending from multilaterals and private sources.

However, whatever the magnitudes involved, from an African perspective, China has been able to fill some major financing gaps for African countries due to three key reasons:

First, China has a more diversified portfolio across the continent than other development partners. A recent study by Morris et al. (2020) at the Center for Global Development analyzed a dataset of 157 countries and compared World Bank and Chinese lending terms in terms of grace periods, interest rates, and maturities for projects over the 2000-2014 period. The authors found that while Chinese lending terms appeared to be more challenging (less concessional) than those of World Bank projects, the loans provided by Chinese institutions tended to be larger than those provided by the World Bank. The average size of loans from China and the World Bank was \$307 million and \$148 million, respectively. This potentially indicates that Chinese banks lend for types of projects that the World Bank and other multilateral institutions do not. The authors also found that China provided loans to 30 countries that the World Bank did not and that Chinese loan terms were comparatively easier (more concessional) than private sector terms.

Second, Chinese banks tend to employ different methodology to assess loans compared to multilateral development banks, which means Chinese actors are able to offer loans in certain sectors, such as infrastructure, more easily and speedily. A 2018 study by the African Development Bank suggested that on average countries had to wait over 5 years for the completion of projects from multilateral banks and non-Chinese bilateral donors-in part due to the challenge of carrying out risk assessment (The Infrastructure Consortium for Africa and African Development Bank 2018, 38). In contrast, China typically determines loan eligibility on the basis of projected returns from a specific project. Which country the project will be built in, or "political risk", as it is sometimes termed, is a minimal consideration. In other words, Chinese lenders look at loans as business propositions and worry less about individual credit history than other bilateral or multilateral lenders might. In addition, Chinese lenders can sometimes fund projects won by a Chinese company through a public tender process, which also speeds processes up. 
Third, China has been open to debt cancellation and restructuring in the past to help African countries fill financing gaps and ease their burden in debt repayment. The official Chinese government position is that China will always respond and support countries that ask for assistance with loan management. A study by Development Reimagined conducted in partnership with the Oxford China Africa consultancy in 2019 found that China wrote off a total of \$3.8 billion in debt worldwide between 2000-2018, of which $\$ 1.7$ billion was owed heavily indebted poor countries (HIPCs). Over the same period, the United Kingdom and the United States provided $\$ 800$ million and $\$ 2.3$ billion, respectively, of debt relief to HIPCs across the world (Development Reimagined 2019). Separately, a study by Rhodium Group found that Chinese lenders have restructured or refinanced over 24 individual loans across the world over the past decade (Kratz et al. 2019).

These three special characteristics about China's role in African development financing are crucial with respect to COVID-19. To help Africa cope with the effects of the COVID-19 pandemic, it is possible for China to offer write-offs for interestfree loans due and unpaid by some of vulnerable countries (Song 2020). However, the longer-term challenges that African economies now face suggest that China's role in African debt financing should not decrease-it should actually increase.

That said, China alone is not enough to help African countries. There is an urgent need for a new type of debt system backed by both China and other developed countries to help African countries receive more finance to meet the Sustainable Development Goals (SDGs).

\subsection{It is urgent to reimagine the debt system}

COVID-19 is not just a huge shock, it is also exposing vulnerabilities in the world system and in individuals. How countries issue, use, and manage debt globally is one of those vulnerabilities. The global debt system is opaque and problematic on many levels. Many countries, not just China, hide their loans, and others hide their debts. Some countries are assessed as having debt problems while others with the same relative levels of debt are not. For instance, Mauritius has the seventh worst debt-to-GDP ratio in Africa according to World Bank figures. Though Kenya's ratio is far lower, Kenya's credit rating was downgraded in 2020 by ratings agencies (Amadala 2020).

Current international loan markets exclude and penalize the poorest countries in the world - the very countries that need loans most. The approach used by Chinese banks to assess projects-i.e., as if they are "business propositions"-is the closest the world currently to a less exclusive system, but it is still not enough. Previous requirements for debt relief and restructurings, and now COVID-19, prove that the Chinese loan model is also vulnerable to external shocks. It is also incredibly challenging to compare loans available on the international marketplace. It is difficult to obtain information on the interest rates, grace periods, or repayment periods for the loans disbursed by many lenders, including China, and in reality these figures are often negotiable. In addition, some lenders coordinate through mechanisms such as the Paris Club or by injecting money into multilateral banks to pool their loans. New 
lender coordinating mechanisms are being created, such as the Africa Private Creditor Working Group (AfricaPCWG). But there are no such coordinating mechanisms for borrowers. The system is incredibly skewed toward meeting the immediate needs of creditors. If a long-lasting solution to COVID-19 debt problems is to be sought, the multilateral debt system itself needs to be rethought and reimagined.

\section{Policy recommendations}

\subsection{African governments must advocate externally and internally for more finance to meet the SDGs in Africa}

The data show clearly that the size of Africa's debt has been growing over the past decade. But such figures on their own are meaningless and subjective. Future financing needs far surpass current debt levels. In 2017, the projected financing needs for Africa related to the SDGs amounted to at least 600 billion dollars a year, equal to almost one-third of Africa's aggregate gross national income (Roethlisberger and Davis 2017). These financing needs cannot be met by Africa's domestic tax-raising and growth alone. This is why it is important to find a way for the international system to follow China and release more finance to Africa. The UN has presented a strategy for financing the SDGs and identified the need to align global economic policies and financial systems with the 2030 Agenda (United Nations SecretaryGeneral 2019). African governments need to push for debt sustainability thresholds and analyses to be reshaped to incorporate and match future needs. Additionally, African governments need to reshape their internal strategies with regard to debt. For example, they need to rethink their debt needs and incorporate those needs into national decision making. They should clarify how each loan addresses their future growth prospects, their resilience to shocks such as COVID-19, and the UN SDGs.

Indeed, sharing more data on debt profiles can preserve these African governments' own reputations, as well as China's. For instance, African governments can develop systems to classify loans and grants, manage their debt profiles, and publish figures on a consistent basis. Only a few countries do this at the moment. While the IMF and World Bank often offer to help with debt transparency, it might be preferrable for African governments to request a third party-potentially funded by but not answerable to any lenders - to help them accomplish this. There already exist systems to build upon, such as aid management systems and the Global Partnership for Effective Development Cooperation.

\subsection{The international community must help African countries find innovative and low-risk ways to access finance}

Even before COVID-19 struck, it was crucial for international society to provide long-term sustainable financial flows to Africa to help it meet the SDGs. COVID19 has only increased this need. Country-level debt must be made both cheaper and more widely available. 
Aside from governments and other actors providing more aid or grants to African countries to enable more concessional (low interest) loans, there are other potentially innovative ways to realize this objective. Based on our assessment, three are particularly important:

First, a "borrower's club" that builds on a model proposed by the UN Economic Commission for Africa (UNECA) could be formed. The club would see African and other countries apply for financing together as a group, using as collateral each other's growth prospects alongside accountability to each other and each other's citizens. The borrowers themselves would be responsible for determining the prioritization of projects across members. Each would provide small, regular, low interest repayments to a central pool and determine their own relevant thresholds or criteria for internal defaults rather than relying on the subjective criteria of their creditors. The club would collate and issue repayments as one to creditors on different schedules while keeping aside a certain amount as a safety cushion or for further collateral. The club would eliminate the individual "country-based" and "political" risks that underlie so many of the constraints of the current debt system. The benefit to the creditors of this club would be that lenders could look at new loans as real growth or business propositions with lower risk, thereby enabling lower interest rates and higher returns.

Second, there should be progress made on establishing the African Monetary Fund (AMF). The AMF is a financial institution planned by the AU to "facilitate the integration of African economies by eliminating trade restrictions and providing greater monetary integration". The AU Assembly adopted the AMF Protocol and Statute at the 22nd AU Summit in June 2014 (The African Union 2014). The AMF is expected to serve and operate as a pool for African Central Bank (ACB) reserves as well as national currencies for AU member states-it will essentially act as Africa's own IMF, its own "lender of last resort". It will, like the IMF, also conduct macroeconomic surveillance of AU member states. However, there is a long way to go to successfully make the AMF happen. It will go into force 30 days after ratification by 15 AU member states. As of June 2019, 12 countries have provided signatures to the AMF Protocol and Statute; Chad is the only country that has also ratified the agreement and made a capital deposit (The African Union 2019). Thus, in the context of the African Continental Free Trade Area, which began implementation on the 1st of January 2021, it is urgent for the AU and its member states to accelerate progress on the AMF to promote a more integrated, sustainable, and equitable African economy that benefits the continent.

Third, Gallagher et al. (2020) propose that IMF member states-as they did after the financial crisis in 2008-2009-issue or reallocate Special Drawing Rights (SDRs) to deal with COVID-19. In April 2021, IMF member states agreed to do just this-to issue an unprecedented US\$650 billion. However, the problem remains that historically, SDRs have been issued in proportion to member states' quotas, which means that the largest countries, which already have their own domestic debt management systems, receive the most SDRs. According to our calculations, African nations will together receive just US $\$ 42$ billion. This is not even enough to cover the budgets that they put aside to fight COVID-19 in 2020, let alone the coming three or 4 years. This is why it is necessary for IMF member states to go further and agree 
to reallocate SDRs to middle- and low-income countries only, or, for example, to everyone but the G20. More or reallocated SDRs would allow countries in debt to exchange those SDRs for finance to put toward existing debts or pay for new expenditures, similar to drawing from a newly accessible trust fund or a business generating equity from new collateral.

\subsection{China is uniquely positioned to help African borrowers}

China has been and is a key driver for helping African countries finance their development. Chinese support will be even more crucial in the post-COVID-19 era and should be increased to help meet African financing gaps. Here, we propose four ways for China to do so:

First, to simply provide a clear signal of its commitment to Africa-for example, at the next FOCAC summit, which will be held in late 2021 in Dakar, SenegalChina could commit to providing African countries with at least \$60-100 billion of financing over the next 3 years, based on continuing needs going forward and with the assumption of a larger proportion of foreign direct investment in comparison to its FOCAC 2018 commitment.

Second, in the coming months, China could also consider restructuring loans for those that request it and even openly set out the "principles" it will use so that countries can come forward with specific calculable proposals that will enable them to take on even more loans-loans that will allow them to diversify their economies or fund infrastructure for e-commerce logistics, for instance. For example, Chinese banks could announce that they will reduce interest rates for low-income countries by two percent and for middle-income countries by one percent. Alternatively, Chinese banks could declare that loan repayment periods will be extended by 5 or 10 years. These measures would provide helpful and comprehensive buffers for African borrowers and, rather than adhering to a "one-size-fits-all" approach, adjust according to countries' actual loan balances. In addition, these measures could constitute best practices for all other lenders, including those from the private sector in the US and Europe, to follow.

Third, how China allocates the capital from its overall commitments to "Africa" as a whole is still somewhat unclear to individual African countries. As a result, it is hard to fully understand how African countries are really benefitting from access to Chinese loans. This also means it is easy for external actors to fabricate stories about China's lending to Africa without understanding context and intentions. It is also quite difficult to acquire official loan information-such as maturity, interest rates, and grace periods for projects - and information important to ensuring public support for Chinese loans-such as local employment figures and local procurement rules-from official Chinese websites. In addition, China's announcements often omit important details. For instance, in 2020, China announced that it had restructured loans or signed debt suspension agreements with 11 African countries, but it remains unclear what the conditions for the loan restructuring were or which 11 African countries signed the agreements (Ministry of Foreign Affairs of the People's Republic of China 2020b). Therefore, having a single mechanism or platform for 
providing this information to African governments would make it easier for them to track and evaluate this information and transmit it to their citizens.

Last, China could help African countries secure changes to the multilateral financing system that are in their interest. China has been helpful so far-for example, by supporting a new issuance of SDRs by the IMF-but it could go a step further and work with African countries on a reallocation formula. China could also share lessons with other donors and multilateral banks on how to better assess project risks. China could also provide technical or financial support to help African countries set up an African Monetary Fund and/or a borrower's club, as discussed earlier in this article.

\section{Conclusion}

Despite seeing fewer cases and deaths compared to the rest of the world, many African countries are instead experiencing a significant economic shock as a result of COVID-19. The effects of this shock will make it very difficult for African countries to grow, collect tax revenue and repay loans this year. However, our analysis does not indicate that this will cause a debt crisis akin to that of the 1990s. In fact, we argue the opposite. COVID-19 has exposed the fact that most countries in the continent need more finance from China and other countries, not less, to cope with the effects of the pandemic and escape the vulnerabilities they face due to the poorly developed structures of their economies. In other words, assessments of Africa's debt situation must take into account the need for more finance in African countries to meet the SDGs. Furthermore, the post-COVID-19 recovery and the achievement of the SDGs in Africa are not only a matter of raising funds, but, more urgently, require the development of a new debt system. China can and should be a key partner for Africa in this endeavor.

Conflict of interest The authors declare that they have no conflict of interest.

\section{References}

African Development Bank. 2018. African economic outlook 2018. https://www.afdb.org/fileadmin/uploa ds/afdb/Documents/Publications/African_Economic_Outlook_2018_-_EN.pdf. Accessed 25 May 2020.

Amadala, Victor. 2020. Kenya's sovereign credit rating placed at "negative" by S\&P. The Star. https:// www.the-star.co.ke/business/kenya/2020-07-16-kenyas-sovereign-credit-rating-placed-at-negativeby-sp/. Accessed 23 Oct 2020.

Amara, Tarek, and Mike Harrison. 2020. Tunisia reopens borders to tourists after halting spread of coronavirus. Yahoo News. https://news.yahoo.com/tunisia-reopens-borders-tourists-halting-095832726. html. Accessed 23 Oct 2020.

Battaile, William, F. Leonardo Hernández, and Vivian Norambuena. 2015. Debt sustainability in subSaharan Africa: unraveling country-specific risks. World Bank Policy Research Working Paper No. 7523.

Development Reimagined. 2019. China's debt relief along with the Belt and Road: what's the story? https://developmentreimagined.com/2019/04/25/chinas-debt-relief-along-the-belt-and-road-whatsthe-story/. Accessed 1 Nov 2020. 
Development Reimagined. 2020. Is Africa drowning in COVID19 debt?. https://developmentreimagined. com/2020/06/12/is-africa-drowning-in-debt/. Accessed 23 Oct 2020.

Fole, Alemayehu Geda. 2003. The historical origin of African debt crisis. Eastern Africa Social Science Research Review 19 (1): 59-89. https://doi.org/10.1353/eas.2002.0012.

Gallagher, Kevin P., Jose Antonia Ocampo, and Ulrich Volz. 2020. IMF Special Drawing Rights: A key tool for attacking a COVID-19 financial fallout in developing countries. Future Development, Brookings Institution. https://www.brookings.edu/blog/future-development/2020/03/26/imf-speci al-drawing-rights-a-key-tool-for-attacking-a-covid-19-financial-fallout-in-developing-countries/. Accessed 25 May 2020.

Green, Mark. 2019. China's debt diplomacy: how Belt and Road threatens countries' ability to achieve self-reliance. Foreign Policy. https://foreignpolicy.com/2019/04/25/chinas-debt-diplomacy/. Accessed 13 Nov 2020.

Horn, Sebastian, Carmen M. Reinhart, and Christoph Trebesch. 2019. China's overseas lending. Working Paper 26050, National Bureau of Economic Research. https://www.nber.org/papers/w26050. Accessed 25 May 2020.

International Monetary Fund. 2020a. The evolution of public debt vulnerabilities in lower income economies. IMF Policy Paper No. 20/003. https://www.imf.org/en/Publications/Policy-Papers/Issues/ 2020/02/05/The-Evolution-of-Public-Debt-Vulnerabilities-In-Lower-Income-Economies-49018. Accessed 25 May 2020.

International Monetary Fund. 2020b. World economic outlook, October 2020: a long and difficult ascent. https://www.imf.org/en/Publications/WEO/Issues/2020/09/30/world-economic-outlook-october2020. Accessed 1 Nov 2020.

Jubilee Debt Campaign. 2018. Africa's growing debt crisis: who is the debt owed to? https://jubileedebt. org.uk/wp/wp-content/uploads/2018/10/Who-is-Africa-debt-owed-to_10.18.pdf. Accessed 25 May 2020.

Khan, Mohsin S. and Simeon Inidayo Ajayi. 2000. External Debt and Capital Flight in Sub-Saharan Africa. International Monetary Fund. https://www.imf.org/external/pubs/nft/2000/extdebt/. Accessed 13 Nov 2020.

Kratz, Agatha, Allen Feng, and Logan Wright. 2019. New data on the "debt trap" question. Rhodium Group. https://rhg.com/research/new-data-on-the-debt-trap-question/. Accessed 25 May 2020.

Xinhua: 2018. Full text of Chinese President Xi Jinping's speech at opening ceremony of 2018 FOCAC Beijing Summit. http://www.xinhuanet.com/english/2018-09/03/c_129946189.htm. Accessed 16 Nov 2020.

Lufumpa, Charles Leyeka. 2020. Post COVID-19: Rebuilding Africa and strengthening its resilience against future economic shocks. African Development Bank. https://www.afdb.org/en/news-andevents/post-covid-19-rebuilding-africa-and-strengthening-its-resilience-against-future-economicshocks-37467. Accessed 16 Oct 2020.

Ministry of Foreign Affairs of the People's Republic of China. 2020a. Foreign Ministry spokesperson Wang Wenbin's regular press conference on November 13, 2020. https://www.fmprc.gov.cn/mfa eng/xwfw_665399/s2510_665401/2511_665403/t1832285.shtml. Accessed 16 Nov 2020.

Ministry of Foreign Affairs of the People's Republic of China. 2020b. Foreign Ministry spokesperson Zhao Lijian's regular press conference on October 12, 2020. https://www.fmprc.gov.cn/mfa_eng/ xwfw_665399/s2510_665401/t1823343.shtml. Accessed 13 Nov 2020.

Morris, Scott, Brad Parks, and Alysha Gardner. 2020. Chinese and World Bank lending terms: a systematic comparison across 157 countries and 15 years. Policy Paper 170, Center for Global Development. https://www.cgdev.org/sites/default/files/chinese-and-world-bank-lending-terms-systematiccomparison.pdf. Accessed 25 May 2020.

Mutize, Mischeck, and McBride Peter Nkhalamba. 2020. A comparative study of economic growth as a key determinant of sovereign credit ratings in Africa. International Journal of Emerging Markets. https://doi.org/10.1108/IJOEM-10-2019-0830.

Nairametrics. 2020. Nigeria records debt service to revenue ratio of $99 \%$ in first quarter of 2020. https:// nairametrics.com/2020/06/13/nigeria-records-debt-service-to-revenue-ratio-of-99-in-first-quarterof-2020/. Accessed 23 Oct 2020.

Olabisi, Michael, and Howard Stein. 2015. Sovereign bond issues: do African countries pay more to borrow?. Journal of African Trade 2 (1-2): 87-109.

Onyekwena, Chukwuka, and Mma Amara Ekeruche. 2019. Is a debt crisis looming in Africa? The Brookings Institution. https://www.brookings.edu/blog/africa-in-focus/2019/04/10/is-a-debt-crisis-loomi ng-in-africa/. Accessed 13 Nov 2020. 
Organization for Economic Co-operation and Development. 2020. Revenue statistics in Africa 2020. https://www.oecd.org/tax/tax-policy/brochure-revenue-statistics-africa.pdf. Accessed 1 Nov 2020.

Roethlisberger, Claudi, and Junior Davis. 2017. Financing needs and debt sustainability in Africa. United Nations Conference on Trade and Development. https://unctad.org/news/financing-needs-and-debtsustainability-africa. Accessed 3 Nov 2020.

Song, Wei. 2020. African "debt issue" needs sound solution. Global Times. https://www.globaltimes.cn/ content/1189475.shtml. Accessed 13 Nov 2020.

State Taxation Administration of the People's Republic of China. 2018. The share of tax revenue in GDP 2018. http://www.chinatax.gov.cn/eng/c101270/c101273/c5107024/content.html. Accessed 1 Nov 2020.

Sun, Yun. 2020. China's changing approach to Africa. The Brookings Institution. https://www.brookings. edu/blog/africa-in-focus/2019/02/04/chinas-changing-approach-to-africa/. Accessed 16 Nov 2020.

The African Union. 2014. Protocol on the establishment of the African Monetary Fund. https://au.int/ sites/default/files/treaties/36417-treaty-0046_-_protocol_on_the_establishment_of_the_african_ monetary_fund_e.pdf. Accessed 9 Nov 2020.

The African Union. 2019. Status list: protocol on the establishment of the African Monetary Fund. https://au.int/sites/default/files/treaties/36417-sl-PROTOCOL\%20ON\%20THE\%20ESTABLIS HMENT\%20OF\%20THE\%20AFRICAN\%20MONETARY\%20FUND.pdf. Accessed 9 Nov 2020.

The Infrastructure Consortium for Africa Secretariat and African Development Bank. 2018. Infrastructure Financing Trends in Africa - 2017. https://www.icafrica.org/fileadmin/documents/Annual_ Reports/IFT2017.pdf. Accessed 25 May 2020.

United Nations Secretary-General. 2019. Roadmap for financing the 2030 agenda for sustainability development, 2019-2021. https://www.un.org/sustainabledevelopment/wp-content/uploads/2019/07/UNSG-Roadmap-Financing-the-SDGs-July-2019.pdf. Accessed 3 Nov 2020.

World Economic Outlook Database. 2020. International Monetary Fund. https://www.imf.org/en/Publi cations/WEO/weo-database/2020/October. Accessed 11 Nov 2020.

\title{
Authors and Affiliations
}

\author{
Hannah Ryder ${ }^{1} \cdot$ Yike Fu $^{1}$ \\ Hannah Ryder \\ hannahryder@developmentreimagined.com \\ 1 Development Reimagined, Beijing, China
}

